\title{
Performance of Dalbergia palo-escrito Rzed. \& Guridi-Gómez, a valuable timber tree, in a coffee plantation in Hidalgo, Mexico
}

\section{Alfonso SUÁREZ-ISLAS ${ }^{1}$ Juan CAPULÍN-GRANDE ${ }^{1}$ José J. MATEO-SÁNCHEz ${ }^{1}$}

${ }^{1}$ Instituto de Ciencias Agropecuarias Universidad Autónoma del Estado de Hidalgo

Tulancingo, Hidalgo

México 43600

Mexico

\section{Auteur correspondant /}

Corresponding author:

Alfonso Suárez-Islas -

alfonso suarez5294@uaeh.edu.mx

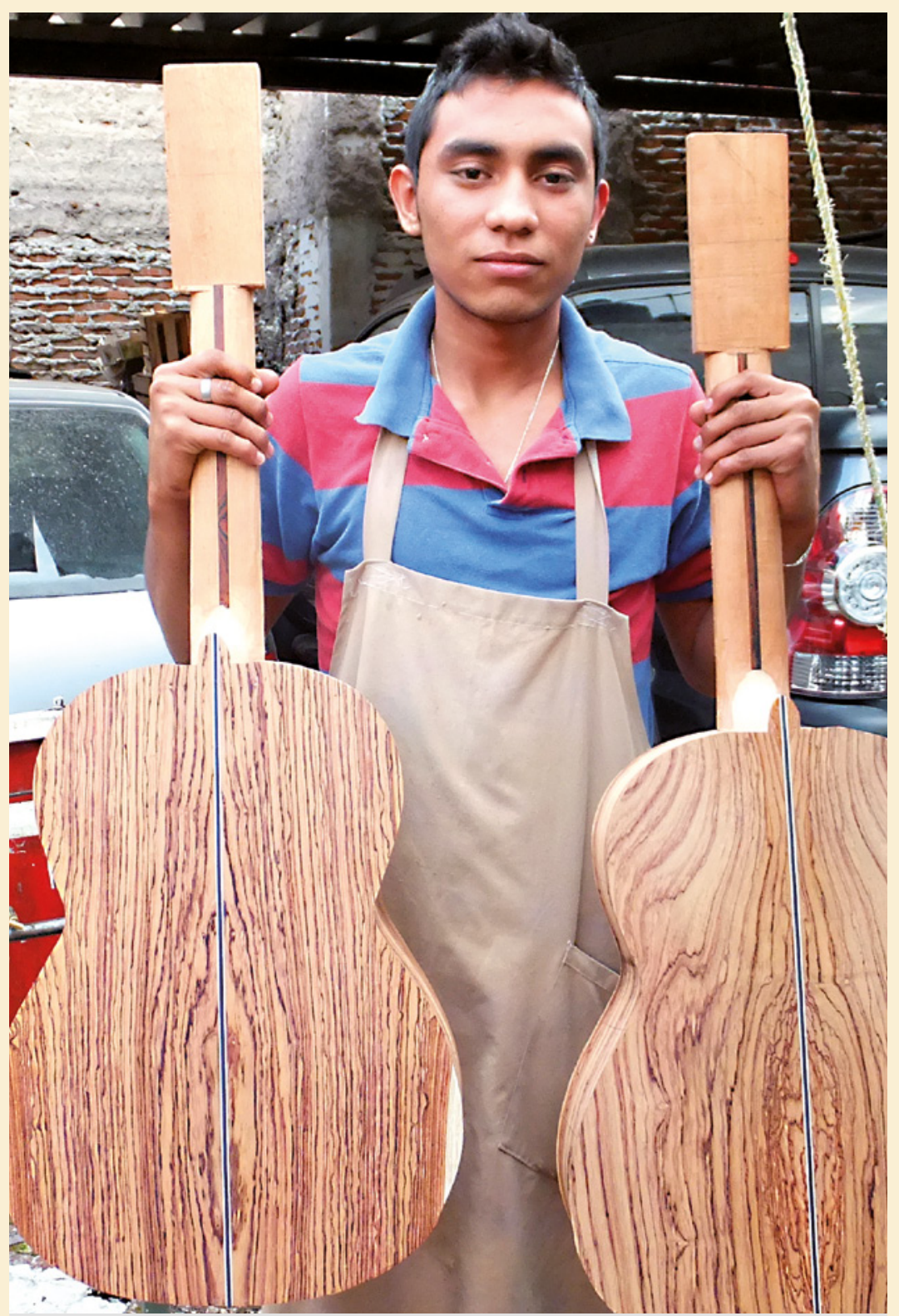

Photo 1.

Young luthier from Paracho, Michoacán showing the back of body of two guitars made with Dalbergia palo-escrito wood. Photo A. Suárez-Islas.

Doi : 10.19182/bft2020.344.a31899 - Droit d'auteur @ 2020 , Bois et Forêts des Tropiques @ Cirad - Date de soumission : 5 otobre 2019 ; date d'acceptation : 20 avril 2020 ; date de publication : $1^{\text {er }}$ juillet 2020 .

\section{- cirad (2)}

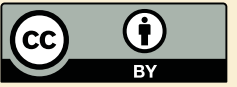

Citer l'article / To cite the article

Suárez-Islas A., Capulín-GrandeJ., Mateo-SánchezJ.J., 2020. Performance of Dalbergia palo-escrito Rzed. \& Guridi-Gómez, a valuable timbertree, in a coffee plantation in Hidalgo, Mexico. Bois et Forêts des Tropiques, 344: 47-57. Doi: https://doi.org/10.19182/bft2020.344.a31899 


\section{RÉSUMÉ}

\begin{abstract}
Qualités d'une essence à bois précieux, Dalbergia palo-escrito Rzed. \& GuridiGómez, plantée dans une zone caféière de l'Hidalgo au Mexique
\end{abstract}

Afin de contribuer à la conservation ex situ et à la reprise de la production de bois de Dalbergia palo-escrito Rzed. \& Guridi-Gómez, une essence commerciale précieuse, celle-ci a fait l'objet d'une plantation d'enrichissement dans une zone caféière située à $830 \mathrm{~m}$ d'altitude dans l'est de l'État de Hidalgo au Mexique. Cette étude avait pour objectif d'évaluer la croissance et l'état de santé de cette essence afin de proposer des recommandations pour la gestion forestière dans ce cadre. La croissance moyenne des arbres à 11 ans d'âge $(n=56)$ présente les valeurs suivantes : diamètre normal, $13,2 \pm 2,9 \mathrm{~cm}$; hauteur totale, $10,9 \pm 1,9 \mathrm{~m}$. Ces valeurs correspondent à une croissance moyenne de $1,2 \mathrm{~cm}$ par an en diamètre et de $1,0 \mathrm{~m}$ par an en hauteur. Des différences statistiquement significatives sont observées pour la croissance en diamètre $(P=0,0001)$ et en hauteur $(P=0,003)$ en fonction de la position des houppiers, la croissance en diamètre et en hauteur étant plus forte pour les arbres aux houppiers exposés au soleil que pour les arbres peu éclairés. Une autre association est observée en ce qui concerne l'infestation par le vrai gui Struthanthus sp., à savoir des écarts de croissance en diamètre $(P=0,002)$ entre les arbres peu et moyennement infestés et les arbres sains, lesquels présentent une croissance plus faible. En revanche, aucun écart de croissance en hauteur n'a été détecté $(P=0,102)$. La croissance en diamètre et en hauteur est comparable à celle d'autres essences précieuses de Dalbergia commercialisées sur le marché mondial, telles que Dalbergia sissoo en Inde et Dalbergia retusa dans des plantations mixtes au Costa Rica. L'étude suggère que l'élagage du gui comme stratégie de contrôle est une pratique de gestion forestière recommandée, ainsi que la libération des arbres mal éclairés de la compétition et la préservation de la canopée d'ombre des autres espèces indigènes précieuse.

Mots-clés : Dalbergia palo-escrito, palissandre mexicaine, plantation d'enrichissement, agroforesterie multiétages, café cultivé sous couvert, Struthanthus sp., Mexique.

\section{ABSTRACT}

\section{Performance of Dalbergia palo-escrito Rzed. \& Guridi-Gómez, a valuable timber tree, in a coffee plantation in Hidalgo, Mexico}

As a contribution to ex-situ conservation and production recovery of the valuable timber tree species Dalbergia palo-escrito Rzed. \& Guridi-Gómez, enrichment planting was undertaken in a coffee plantation at $830 \mathrm{~m}$ above sea level in the east of the State of Hidalgo, Mexico. The purpose of this study was to assess the growth and health status of this species in order to put forward forest management recommendations. Average growth at 11 years of age $(n=56)$ was as follows: normal diameter, $13.2 \pm 2.9 \mathrm{~cm}$; total height, $10.9 \pm 1.9 \mathrm{~m}$. These values represent a mean annual increase of $1.2 \mathrm{~cm} /$ year in diameter and $1.0 \mathrm{~m} /$ year in height. Significant statistical differences in diameter growth $(P=0.0001)$ and height growth $(P=0.003)$ were observed as a function of crown position; growth, both in diameter and height, was highest in trees with emergent crowns in comparison with poorly lit trees. An association was also found concerning infestation by Struthanthus sp. true mistletoe: differences in diameter growth $(P=0.002)$ were found between trees with mild and medium infestation in comparison with healthy trees, which showed less growth. On the other hand, no height growth differences were detected ( $P=0.102)$. Diameter and height growth were comparable to other commercially valuable species of fine Dalbergia timber on the international market, such as Dalbergia sissoo in India and Dalbergia retusa in mixed plantations in Costa Rica. The study suggests pruning out the mistletoe as a control strategy is a recommended forest management practice, as well as releasing poorly illuminated trees from competition and preserving the shade canopy of other valuable native species.

Keywords: Dalbergia palo-escrito, Mexican Rosewood, enrichment planting, multi-strata agroforestry system, shade-grown coffee, Struthanthus sp., Mexico.

\section{RESUMEN}

\section{Rendimiento del Dalbergia palo-escrito Rzed. \& Guridi-Gómez, un valioso árbol maderable, en una plantación de café en Hidalgo, México}

Como contribución a la conservación ex situ y la recuperación de la producción de la valiosa especie maderable Dalbergia palo-escrito Rzed. \& Guridi-Gómez, se realizó una plantación de enriquecimiento en un cafetal a 830 m por encima del nivel del mar en el este del estado de Hidalgo, México. El objetivo de este estudio fue evaluar el crecimiento y el estado de salud de esta especie para formular recomendaciones de gestión forestal. El crecimiento medio de los árboles $(n=56)$ a los 11 años de edad fue el siguiente: diámetro normal, 13,2 $\pm 2,9 \mathrm{~cm}$; altura total, $10,9 \pm 1,9 \mathrm{~m}$. Estos valores representan un incremento medio anual de

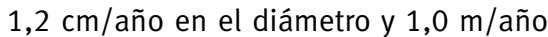
en la altura. Se observaron diferencias estadísticas significativas en el crecimiento diametral $(P=0,0001)$ y el crecimiento en altura $(P=0,003)$ en función de la posición de la copa. El crecimiento, tanto diametral como en altura, era más elevado en árboles con copas emergentes comparados con los árboles poco iluminados. También se evidenció una relación con la infestación de muérdago verdadero Struthanthus sp.: se encontraron diferencias en el crecimiento diametral $(P=0,002)$ de árboles con infestación leve y media comparados con árboles sanos, que mostraron un crecimiento menor. Por otro lado, no se detectaron diferencias en el crecimiento en altura $(P=0,102)$. El crecimiento diametral y en la altura resultaron comparables con los de otras especies comercialmente valiosas de madera fina Dalbergia en el mercado internacional, como Dalbergia sissoo en la India y Dalbergia retusa en plantaciones mixtas de Costa Rica. El estudio sugiere que la poda del muérdago como estrategia de control es una práctica silvicultural recomendada, así como la liberación de los árboles mal iluminados de la competencia y la preservación del dosel de sombra de otras especies nativas valiosas.

Palabras clave: Dalbergia palo-escrito, palisandro mexicano, plantación de enriquecimiento, sistema agroforestal estratificado, café cultivado bajo sombra, Struthanthus sp., México. 


\section{Introduction}

Cloud forests account for $1 \%$ of the national territory in humid mountain ranges; however, these ecosystems are under increasing pressure by migratory agriculture, fruit tree cultivation, extensive stockbreeding, illegal logging, and urban expansion (Rzedowski, 2006; CONABIO, 2010). In the state of Hidalgo, the transformation of cloud forest areas into agricultural and stockbreeding resources threatens the existence of the habitat; cloud forests in the region were traditionally thinned to establish coffee (Coffea arabica L.) plantations, and native trees were kept as shade canopy, but coffee plantations have been increasingly transformed into permanent pasture and agricultural lands (Cartujano et al., 2002); low profitability and diseases associated with coffee plantations have dwindled this activity (López-Pérez, 2002).

Sustainable strategies are needed to reconcile production and development interests with ecosystem services for the conservation and recovery of the cloud forest, including its arboreal component. The traditional shade coffee agroforestry system allows the preservation of native tree species and associated fauna, such as migratory birds (González-Espinoza et al., 2012). Some shade coffee plantations present a multi-strata structure similar to that of cloud forests; consequently, they can, under management, contribute to the conservation of the landscape matrix as a complementary use of the land (Jardel-Peláez et al., 2014); therefore, this agroforestry system should be promoted especially in buffer zones (CONABIO, 2010). Timber tree enrichment plantings are particularly suitable to improve the economic and social sustainability of coffee plantations (Salgado, 2012). Research and experimentation focused on cloud forest species with forestry potential are necessary to develop production alternatives that counter the transformation of forests into pasturelands and low-productivity crops (Jardel-Peláez et al., 2014).

An interesting tree species for coffee plantation economic and biological enrichment purposes is Dalbergia palo-escrito Rzed. \& Guridi-Gómez. This tree grows in the Sierra Madre Oriental, where small groups are distributed among the states of Hidalgo, Querétaro, and San Luis Potosí, mainly in secondary forests, as living fences, and in family orchards, although the species also grows in primary cloud forests where it reaches up to $35 \mathrm{~m}$ high, but it is scarce (Rzedowski and Guridi-Gómez, 1988). More recently Cervantes et al. (2019) detected some disjunct populations from the states of Morelos, Guerrero and Oaxaca. Dalbergia is mainly appreciated for its easy-to-work precious wood, characterized by its resonance properties, vivid color, and contrasting grain pattern; it is often used for making violins and guitars, especially in Paracho, Michoacán, a town known worldwide in the luthiery industry (Pérez-Olvera et al., 2002; Carmona-Valdovinos, 2003).

The species is currently included under threatened risk category by the Mexican Official Norm NOM-059-SEMARNAT-2010 (DOF, 2019). Previously during the 17th Conference of the Parties of Convention on National Trade in Endangered Species of Wild Fauna and Flora (CITES, 2016), D. palo-escrito was included in the Appendix II along with 12 other Mexican timber species from Dalbergia. González-Espinoza et al., (2011) it can be tagged as a critically endangered species based on International Union for Conservation of Nature (IUCN) criteria.

Tree and forest measurement data are necessary for the efficient management of these plantations and to support decisions associated with the use of forestry treatments and techniques conducive to the growth of trees and associated crops, for ultimately decreasing costs and environmental impact (Detlefsen et al., 2012). Nevertheless, $D$. palo-escrito tree growth variables reports are practically inexistent (Rzedowski and Guridi-Gómez, 1988; Winfield et al., 2016), and as Millet et al. (2013) have reported, this gap has been identified as an important limitation in using native species for biodiversity preservation purposes, especially among small farmers (Schneider et al., 2014).

In this context, the present study describes the enrichment of coffee plantations using $D$. palo-escrito in the state of Hidalgo as an agroforestry strategy that seeks to serve two different purposes: maintenance of tree cover (source of germplasm) and wood production for the manufacture of string musical instruments, used for the interpretation of traditional musical style "son huasteco". The present study sought to characterize a D. palo-escrito and coffee agroforestry system and assess its tree growth variables and phytosanitary status of infestation by true mistletoe. The obtained results allow for forest management recommendations focused on the growth of this species as shade canopy as part of an integral agroforestry management strategy to promote plantings of Dalbergia in coffee plantations in the state of Hidalgo, Mexico.

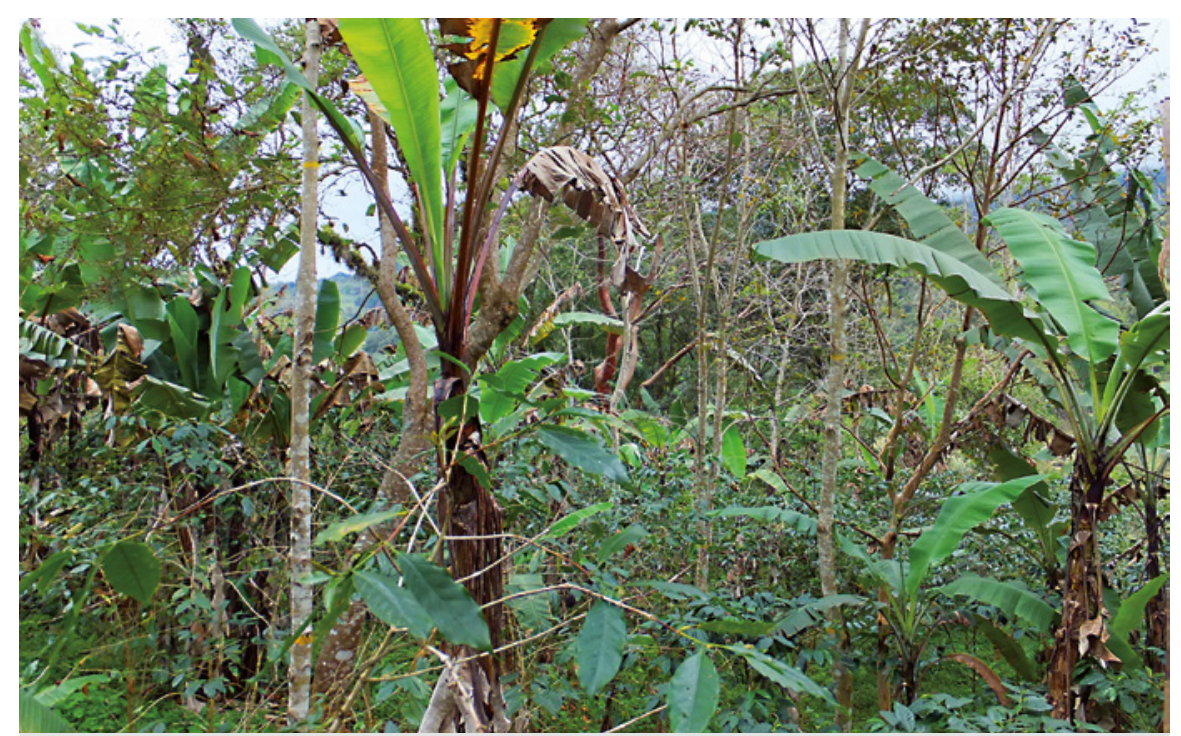

Photo 2.

View of the permanent measuring plot. There are two strata, Dalbergia palo-escrito trees in the upper shade canopy and a perennial crop layer of Musa acuminata and Coffea arabica. Photo A. Suárez-Islas. 


\section{Methods}

\section{Plantation site}

Dalbergia palo-escrito trees were planted in October 2004 as enrichment planting in a coffee agroforestry system located in a ranch named El Petatillo $\left(20^{\circ} 20^{\circ} 08^{\prime \prime} \mathrm{N}\right.$, $98^{\circ} 13^{`} 36^{\prime \prime} \mathrm{W}$; 830 m.a.s.l.), in the municipality of Tenango de Doria, Hidalgo, Mexico (figure 1). Mean annual temperature in the area is $22{ }^{\circ} \mathrm{C}$, and mean annual precipitation is $2,050 \mathrm{~mm}$ (UNAM, 2013). Coffee plantation size was 0.79 ha. Coffee plants of the Caturra variety (Coffea arabica L.) were spaced $1.5 \times 2.5 \mathrm{~m}$ apart. Shade trees such as jonote colorado (Trema micrantha (L.) Blume), chaca (Bursera simaruba (L.) Sarg.), álamo (Platanus mexicana Moric.), and cedro rojo (Cedrela odorata L.) were also present.

A total of 99 young $D$. palo-escrito trees were planted in a low-shade area and gaps of the coffee plantation, spaced $4.5 \times 5 \mathrm{~m}$ apart, among some native trees of natural regeneration and crops introduced by the farmer, such as Musa acuminata Colla, a banana species, which were distributed in a random pattern (table I). The provenance of the $D$. palo-escrito seeds was the village of Chachala, in the municipality of Tlanchinol, Hidalgo (20 $58^{\prime} 11.3^{\prime \prime} \mathrm{N}, 98^{\circ} 41^{\prime}$ 59.6" W; 1,392 m.a.s.l.). At the moment of planting, trees averaged $32 \mathrm{~cm}$ in height and $3 \mathrm{~mm}$ in diameter at the root collar. The area where $D$. palo-escrito trees were planted in 2004 was outlined as a Permanent Measurement Plot (PMP), which size was 0.22 ha, faced north, and had an average slope of $17 \%$. During the first five years of planting, the farmer gradually cut down the naturally regenerating trees (especially Trema micrantha) that competed for light with the $D$. palo-escrito trees, until they were completely exposed to light. The farmer only allowed the regeneration of timber trees (Juglans pyriformis Liebm., Diphysa sennoides Benth. and Leucaena sp.) and some fruit (Persea schediana Nees) trees near the places where $D$. palo-escrito trees died.

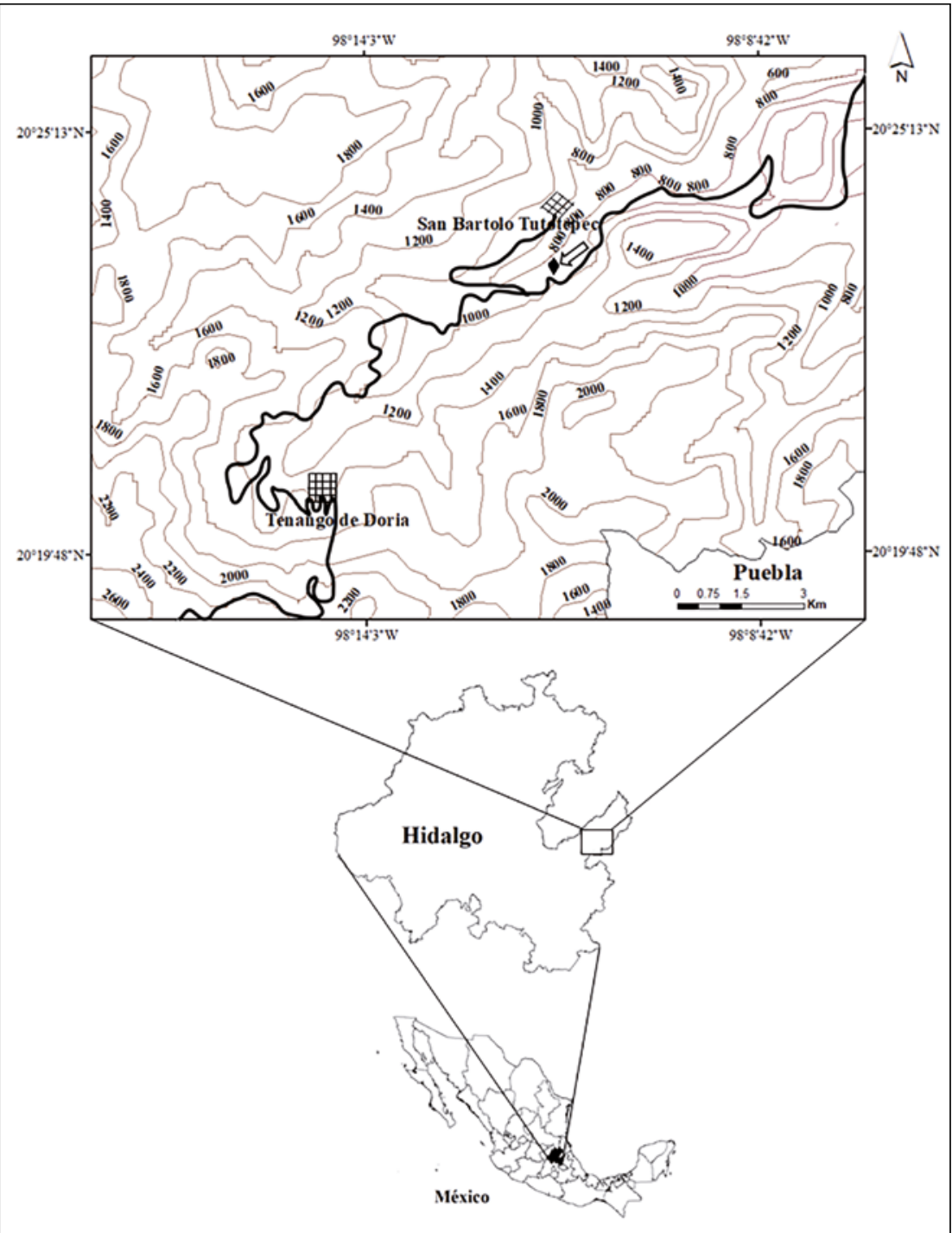

Figure 1.

Location of the ranch "El petatillo" (arrow) $1.5 \mathrm{~km}$ south of the village of San Bartolo Tutotepec, Hidalgo, Mexico. Bounded lines represent contours in meters above sea level, thick line represents paved road.

\section{Agroforestry characterization}

Vegetation was described by classifying it into two strata: perennial crops and shade canopy. Total height $(h)$ of each individual plant was measured using a Vertex III (C) Haglöf Sweden $A B$ ) hypsometer and its auxiliary tool (transponder) with an accuracy of $+/-10 \mathrm{~cm}$. Normal diameter $(d)$ of each tree and shrub (including Musa acuminata pseudostalks), was measured using a steel diameter tape measure at an accuracy of $+/-1 \mathrm{~mm}$. Soil was sampled at two different microsites inside the PMP, one of them with a slope of $17 \%$, whereas the other was almost flat (2\% slope). Three subsamples were collected at each site and mixed as composite samples of soil from depths between $0-30 \mathrm{~cm}$. These samples were subjected to chemical and physical analyses as described in the Mexican Official Norm (NOM-021-SEMARNAT, 2002).

\section{Tree measurement and phytosanitary assessment}

Each D. palo-escrito tree was assigned a control number, which was painted on the tree trunk using acrylic paint. Measurements of $h$ and $d$ were taken for $D$. palo-escrito (and for the rest of shade canopy trees) during October and November, 2015, i.e., when the trees were 11 years old; mean annual increase ( $m a i$ ) was determined based on these data using the equation $m a i=X_{t} / t$, where $X_{t}$ represents the tree variable measure until the moment represented by $t$, which corresponds to age in years.

Additionally, we assessed the sociological position of tree crowns as a measure to determine the amount of light that the trees received in comparison with the rest of the trees in the stratum 
using the Dawkins index (Alder and Synnott, 1992): 5 - emergent crown; 4 - crown completely exposed to vertical light; 3 - crown partially lit vertically; 2 - crown lit laterally only; 1 - no significant direct light on crown. Crown position following Dawkins index provides a good estimation of crown illumination (Keeling and Phillips, 2007).

Infestation by true mistletoe Struthanthus sp. was the main phytosanitary problem in the plantation. This plant is hemiparasitic, it presents epicortical roots that run through the surface of the host tissue and form an intermittent haustorial connection, where substances are released that degrade the cell wall of the host's vessels; as a consequence, there is chlorosis in leaves, low retention and after a while, the death of branches and tips of the host (Cibrián and Alvarado, 2007). Infestation by true mistletoe was assessed using the fourclass system proposed by Vázquez (1993), which consists in establishing the volume of the crown as $100 \%$, and then the degree of infestation is visually assessed and given values from 0 to 3 according to class intervals: (0) healthy, no apparent infestation; (1) mild, 1 to $30 \%$ infestation; (2) medium, 31 to $60 \%$ infestation; (3) severe, 61 to $90 \%$ infestation.

\section{Analysis of tree measurement and phytosanitary variables}

Tree measurement data were grouped based on the sociological position of the crown and the degree of infestation by mistletoe. A contingency table was built considering these two variables as inputs, and the $\chi^{2}$ test was employed to assess independence between variables. Each variable was subjected to a separate, univariate variance analysis considering only the data that met normality and variance homogeneity assumptions. Variable means were compared by Tukey's test $(P \leq 0.01)$ using IBM's SPSS Statistics 19.
Table I.

Agroforestry measurement parameters in a Dalbergia palo-escrito enrichment planting in a coffee plantation. Permanent Measurement Plot (PMP) surface $=0.22$ ha

\begin{tabular}{|l|r|l|l|l|}
$\begin{array}{l}\text { Stratum } \\
\text { Species }\end{array}$ & $\begin{array}{c}\text { Number of } \\
\text { individuals } \\
\text { or bushes }\end{array}$ & \multicolumn{1}{|c|}{$\begin{array}{c}\text { Height } \mathbf{( m )} \\
\text { mean and } \\
\text { range [-] }\end{array}$} & $\begin{array}{c}\text { Diameter } \mathbf{( c m )} \\
\text { mean and } \\
\text { range [-] }\end{array}$ & $\begin{array}{c}\text { Basal area } \\
\left(\mathbf{m}^{2}\right)\end{array}$ \\
\hline Shade trees & 70 & 13.04 & 26.19 & 2.1051 \\
\hline Dalbergia palo-escrito & 56 & $10.9[6.5-15]$ & $13.2[7.6-18.1]$ & 0.8209 \\
\hline Juglans pyriformis & 5 & $10.9[9.6-13.4]$ & $15.7[10.2-23.9]$ & 0.1059 \\
\hline Diphysa sennoides & 2 & $8.8[7.1-10.5]$ & $11.05[8.1-14]$ & 0.0205 \\
\hline Ficus sp. & 2 & $8[6-10]$ & $36.6[23-76.5]$ & 0.6990 \\
\hline Persea schiedeana & 2 & $15.4[14.5-16.2]$ & $29.1[19.2-39]$ & 0.1195 \\
\hline Dendropanax arboreus & 1 & 19 & 56 & 0.2463 \\
\hline Leucaena sp. & 1 & 20 & 19.7 & 0.0305 \\
\hline Unknown & 1 & 11.3 & 28.2 & 0.0625 \\
\hline Perennial crops & 297 & 3.5 & 7.45 & 2.4691 \\
\hline Coffea arabica & 240 & $3.4[2.8-3.9]$ & $2.3[1.6-4.5]$ & 0.4786 \\
\hline Musa acuminata & 57 & $3.6[2-9.5]$ & $12.6[6-30]$ & 1.9905 \\
\hline & & & & \\
\hline
\end{tabular}

\section{Results}

\section{Agroforestry characterization}

Site occupation, measured as total basal area $(G)$, was $9.45 \mathrm{~m}^{2} /$ ha, $39 \%$ of which corresponded to $D$. palo-escrito and the rest to seven other species of trees of natural regeneration (table I). Survival of $D$. palo-escrito at 11 years of age was $57 \%$; average growth was $13.2 \pm 2.9 \mathrm{~cm}$ in $d$ and $10.9 \pm 1.9 \mathrm{~m}$ in $h$, which represented a mean annual increase (mai) of $1.2 \mathrm{~cm} /$ year in $d$ and of $1.0 \mathrm{~m} /$ yearin $h$. The perennial crop stratum occupied a total $G$ of $11.09 \mathrm{~m}^{2} / \mathrm{ha}, 81 \%$ of the site was occupied by Musa sp.

Concerning soil properties, differences in particle content were observed between the two microsites, although both belonged to the same texture class (table II). Apparent density (Ade) was lower in the almost flat microsite due to

Table II.

Soil physical and chemical properties in a Dalbergia palo-escrito enrichment planting in a coffee plantation.

\begin{tabular}{|c|c|c|c|c|c|c|c|}
\hline \multirow[t]{2}{*}{ Microsite } & \multirow{2}{*}{$\begin{array}{l}\text { Ade } \\
\mathrm{g} / \mathrm{cm}^{3}\end{array}$} & \multicolumn{3}{|c|}{ Proportion of particles (\%) } & \multirow{2}{*}{$\begin{array}{c}\text { Texture } \\
\text { class }\end{array}$} & \multicolumn{2}{|c|}{ Color description } \\
\hline & & Sand & Slit & Clay & & Key & Color \\
\hline Flat terrain & 1.04 & 27 & 35 & 38 & Clay-rich loam & 10YR2/2 & Very dark brown \\
\hline Sloped terrain & 1.10 & 31 & 34 & 35 & Clay-rich loam & 10YR3/2 & Dark brown-gray \\
\hline & pH & MO & C & Nt & & $\begin{array}{c}\text { CIC } \\
(\text { Cmols } / \mathrm{kg})\end{array}$ & \\
\hline Flat terrain & 5.52 & 7.85 & 4.55 & 0.39 & & 8.9 & \\
\hline Sloped terrain & 5.85 & 5.50 & 3.12 & 0.27 & & 5.4 & \\
\hline
\end{tabular}


the accumulation of organic matter (OM), which resulted in increased soil volume and microporosity. Due to the presence of $\mathrm{OM}$, soil color was dark brown in the sloped microsite and very dark brown in the almost flat microsite. According to NOM-021-SEMARNAT (2002), which prescribes classification criteria for soil parameters, soil $\mathrm{pH}$ was classified as moderately acid; the flat site presented higher acidity.

\section{Relationship between crown position and mistletoe infestation}

Pearson's $\chi^{2}$ test determined that no relationship between crown position and mistletoe infestation existed at the time of assessment $\left(\chi_{12,0.05}^{2}=12.596 \mathrm{P}=0.399\right)$ (table III). Thus, increases in diameter and height were analyzed independently of crown position and mistletoe infestation.

\section{Table III.}

Contingency table: infection by true mistletoe $\mathrm{X}$ crown position.

$$
\chi^{2} \text { Pearson }_{12,0.05}=12.596, \mathrm{P}=0.399 \text {. }
$$

\begin{tabular}{|c|c|c|c|c|c|c|}
\hline \multirow[b]{2}{*}{$\begin{array}{l}\text { Infestation by true } \\
\text { mistletoe (Vázquez, 1993) }\end{array}$} & \multicolumn{6}{|c|}{ Crown position (Dawkins index) } \\
\hline & $\begin{array}{c}\text { Emerging } \\
\text { vertical } \\
\text { light }\end{array}$ & $\begin{array}{c}\text { Full } \\
\text { vertical } \\
\text { light }\end{array}$ & $\begin{array}{c}\text { Partial } \\
\text { light }\end{array}$ & $\begin{array}{c}\text { Oblique } \\
\text { significant } \\
\text { light }\end{array}$ & No & Total \\
\hline Healthy & 1 & 7 & 3 & 5 & 5 & 21 \\
\hline Mild & 7 & 11 & 3 & 5 & 1 & 27 \\
\hline Medium & 2 & 3 & 1 & 0 & 0 & 6 \\
\hline Severe & 1 & 1 & 0 & 0 & 0 & 2 \\
\hline Total & 11 & 22 & 7 & 10 & 6 & 56 \\
\hline
\end{tabular}

\section{Table IV.}

Dalbergia palo-escrito growth (mean \pm standard deviation) as a function of crown position at 11 years of age. The crown position is related to light. Means with different letters in a column indicate highly significant statistical differences according to Tukey's test $(P<0.01)$. Diameter: $F=10.271$, $P=0.0001$; Height: $F=4.708, P=0.003$.

\section{Crown position \\ (Dawkins index)}

Emerging (5)

Full vertical light (4)

Partial vertical light (3)

Oblique light (2)

No significant light (1)

\begin{tabular}{c} 
Num \\
of $t$ \\
11 \\
2 \\
\hline
\end{tabular}

Number

of trees

22

7

10

6

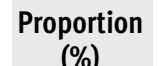

(\%)

20

39

13

18

11

\section{Normal diameter} (cm)

$16 \pm 1.67 \mathrm{a}$

$13.99 \pm 2.11 \mathrm{ab}$

$12.37 \pm 2.8 b c$

$10.82 \pm 2.41 \mathrm{c}$

$10.52 \pm 2.51 c$
Total height

(m)

$12.43 \pm 1.59 a$

$11.18 \pm 1.8 \mathrm{ab}$

$10.56 \pm 1.49 a b$

$9.81 \pm 1.8 b$

$9.83 \pm 1.38 b$

\section{Table V.}

Dalbergia palo-escrito growth (average \pm standard deviation) based on degree of infestation by true mistletoe at 11 years of age. Means with different letters in a column indicate highly significant statistical differences according to Tukey's test $(P<0.01)$. Diameter: $F=7.264, P=0.002$; Height: $F=2.388, P=0.102$.

\section{Infestation by true mistletoe (Vázquez, 1993)}

Proportion

(\%)

Normal diameter

$$
\text { (cm) }
$$

$11.51 \pm 2.83 b$

$14.72 \pm 2.43 a$

$13.85 \pm 0.78$

\begin{tabular}{cc|}
\hline 38 & $11.51 \pm 2.83 b$ \\
\hline 48 & $14.22 \pm 2.53 a$ \\
11 & $14.72 \pm 2.43 a$ \\
\hline 4 & $13.85 \pm 0.78$
\end{tabular}

Total height

(m)
Mild (1)

Medium (2)

Severe (3)
Healthy (0)

27

6

\section{Growth analysis based on amount of light on crowns}

Dalbergia palo-escrito trees with emergent crowns and complete exposure to vertical light accounted for the highest proportion (59\%) of the shade canopy occupied by this species. Highly statistically significant growth differences were observed in $d(\mathrm{P}=0.0001)$ and $h(\mathrm{P}=0.003)$ as a function of the sociological position occupied by the crown in the canopy: growth increased as the light received by the tree's crown increased (table IV). Trees in the category of emergent crown (5) averaged $5.84 \mathrm{~cm}$ more in diameter than trees whose crowns received no significant direct light (category 1); concerning height, plants in the emergent crown category (5) averaged $2.6 \mathrm{~m}$ more than plants in the categories that received light laterally only (2) or lesser.

\section{Analysis based on degree of infestation by mistletoe (Struthanthus sp.)}

Almost half (48\%) of D. paloescrito trees presented a mild degree of infestation by mistletoe Struthanthus sp., whereas $38 \%$ presented no infestation. Highly significant statistical differences were observed when associating tree diameter with degree of infestation by mistletoe $(P=0.002)$; diameters of trees presenting mild and medium degrees of infestation were larger (2.71 and $3.21 \mathrm{~cm}$ in average, respectively) than diameters of healthy trees. No significant statistical differences were observed concerning tree height (table V). 


\section{Discussion}

\section{Agroforestry characterization}

The recommended density of timber trees in a coffee plantation at the end of the turn is between 70 and 156 trees/ha, depending on species and site quality (Salgado, 2012). In the present study, 11-year-old $D$. palo-escrito trees presented a density of 251 trees/ha, which represents a margin of 38 to $72 \%$ of trees due to thinning or mortality until the end of the turn (still unknown). It should also be borne in mind that a density of 63 trees/ha of trees of other species was determined, among which the $G$ of large individuals such as Ficus sp. was outstanding, which increases the need to thinning of this natural regeneration trees as the $D$. palo-escrito harvest turn approaches to adjust tree density to the growth space required by agricultural and timber trees.

There is no harvest turn information for $D$. palo-escrito. With the mean annual increase (mai) in diameter obtained in this study $(1.2 \mathrm{~cm} /$ year $)$, a harvest turn of 37.5 years could be preliminarily estimated to obtain a minimum cutting diameter (MCD) of $45 \mathrm{~cm}$. However, this diameter must be determined based on the existence of useful heartwood to obtain pieces for the manufacture of string musical instruments and furniture. Furthermore, the mai in $d$ will most likely decrease as the biological turn is reached (López and Villalba, 2015); therefore the estimated turn of 37.5 years will increase as data on trees with a $d$ close to the MCD become available.

Although the growth data obtained is from a single experimental plantation, some preliminary comparisons can be made with other Dalbergia species of precious wood of interest to international trade. The increases in $D$. palo-escrito in $d$ and $h$ were similar to the increases in other Dalbergia plantations in different countries of the tropics. In Guatemala, Méndez-Paiz and SerechVan Haute (2018) report a mai of $1 \mathrm{~cm} /$ year for $d$ and $1 \mathrm{~m} /$ year in $h$ for $D$. stevensonii Standl. in plantations of 17 years of age. A similar observation was made in single-species and mixed-species 68 months of age plantations of $D$. retusa Hemsl. in the dry tropical region of Costa Rica, where mai was found to be $1.3 \mathrm{~cm} /$ year for $d$ and $1 \mathrm{~m} /$ year for $h$ (Piotto et al., 2004), so the species was classified as low-growth for such conditions. In India, Parrotta (2000) reported increases of 1 to $2 \mathrm{~cm} /$ year in $d$ for $D$. sisso Roxb. ex DC plantations between 5 and 30 years old. Similarly, Costa et al. (2015), in Brazil, reported an mai of $0.81 \mathrm{~cm} /$ year for the first 22 years of a $D$. nigra (Vell.) Allemão ex Benth plantation.

In our study, very high contents of organic matter $(\mathrm{OM})$ and carbon (C) were found in the nearly flat microsite and high contents were found in the sloped microsite; both sites were found to be rich in total nitrogen (Nt). Slope has been observed to play an important role in nutrient accumulation (Ramos et al., 2015); flat terrain often presents the best conditions, mainly due to less water drainage carrying away nutrient-rich soil particles.

\section{Growth analysis based on amount of light on crowns}

A positive association between growth in $d$ and the sociological position of the crown (as a function of the amount of light received by the crown) has been reported in studies on different tropical species (Finegan et al., 1999; Manzano-Méndez et al., 2010). However, there are other variables that affect the association between illumination and diameter, such as crown shape, crown diameter, topography, vine infestation, and forest density (Galván et al., 2005). For example, in a study on Caesalpinia gaumeri Greenm. the highest values of growth increases in $d$ in trees of the largest diameter categories, with better crown quality, and receiving sunlight completely (Interián-Ku et al., 2014).

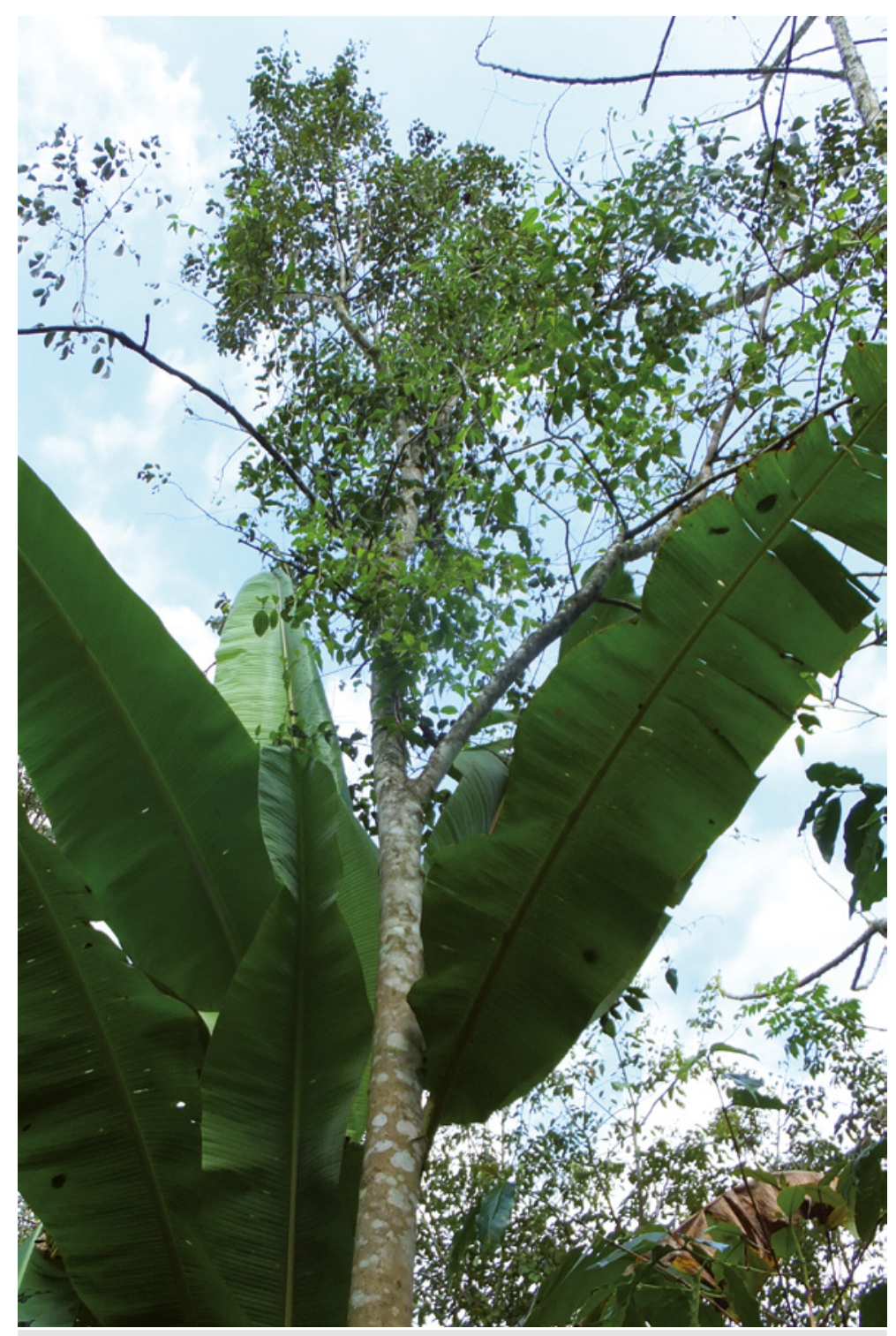

Photo 3.

Dalbergia palo-escrito in the emerging crown category without true mistletoe infestation. These types of trees have the greatest growth potential and represent the forestry target trees. Photo A. Suárez-Islas. 


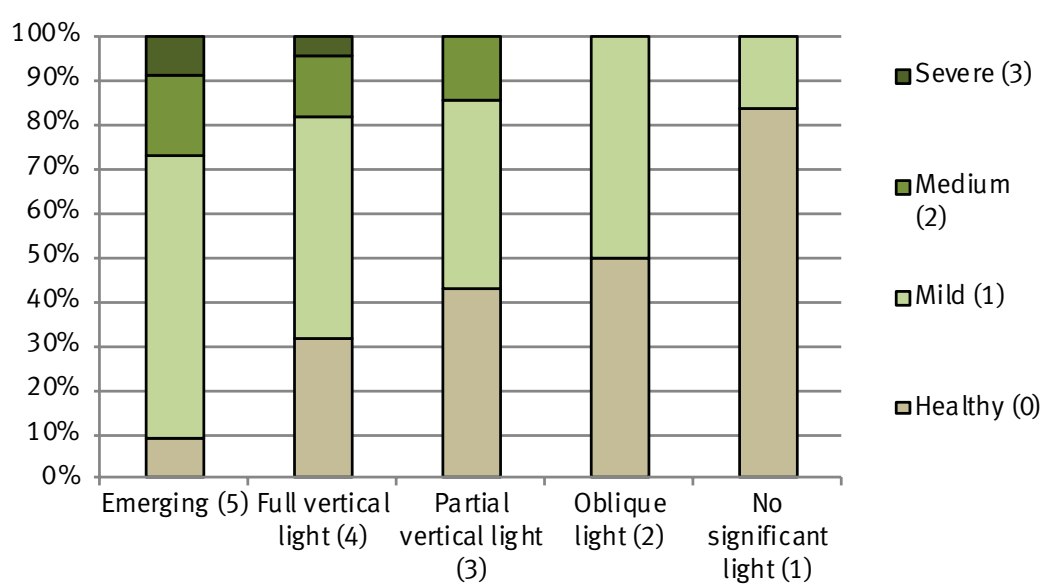

Figure 2.

Percentage distribution of infestation by true mistletoe (Struthanthus sp.) and crown position ( $X$ axis) of Dalbergia palo-escrito. Crown position was assessed using Dawkins index (Alder and Synnott, 1992) and infestation by true mistletoe by the four-class system proposed by Vázquez (1993).

\section{Implications for management and conservation}

Results of the present study allowed for the assessment of $D$. palo-escrito as a precious wood species for coffee plantation enrichment in the region and to preserve this endangered native tree species. Measured diameter and height growth rates were found to be similar to those of other Dalbergia species of interest for the international trade of precious woods, which represents an opportunity to promote this tree and contribute to diversifying the coffee agroecosystem in the region. Moreover, as in the case of other Dalbergia species, which form symbiotic associations with nitrogenfixing bacteria (Sprent and Parsons, 2000), $D$. palo-escrito may also form this symbiosis

\section{Analysis based on degree of infestation by true mistletoe (Struthanthus sp.)}

In the present study, we observed an association between true mistletoe infestation and growth diameter: trees with the highest diameter growth, whose crowns were located in positions where they received the most light, also presented the highest degrees of infestation (figure 2). Additionally, a direct linear correlation $(r=0.852, p=0.001)$ was detected between trunk diameter and crown diameter, which means that trees whose crowns had larger diameters were also more intensely infested. The same result has been observed in Brazil in the leguminous shrub Mimosa calodendron Mart. ex Benth.; individuals presenting larger crown diameters were also the most affected by the hemiparasite Struthanthus flexicaulis (Mart. ex Schult. f.) Mart. (Mourão et al., 2009). True mistletoe is a heliophyte organism, and it develops best at high temperatures; birds that spread its seeds prefer high spots on the tallest trees, so the infestation process takes place from the top to the bottom of the crown (Acosta and Cházaro, 1992; Olsen, 2003). This could be the reason why the trees with the widest canopies and the largest diameters are the trees with the highest infestation of this hemiparasite plant.

In the present study, graphic analysis of true mistletoe infestation intensity and sociological position of the crown suggested that the infestation was spreading to the trees whose crowns were less lit (figure 2), which could further affect decreased diameter and height growth in the future. Howell and Mathiasen (2004) point out that time since infection is a crucial factor because the parasite absorbs more water and minerals from its hosts as it grows, which often leads to decreased host growth. Moreover, mistletoe affects the host's plant architecture, sometimes reducing its photosynthetic capacity and respiration rate (Ehleringer et al., 1985).

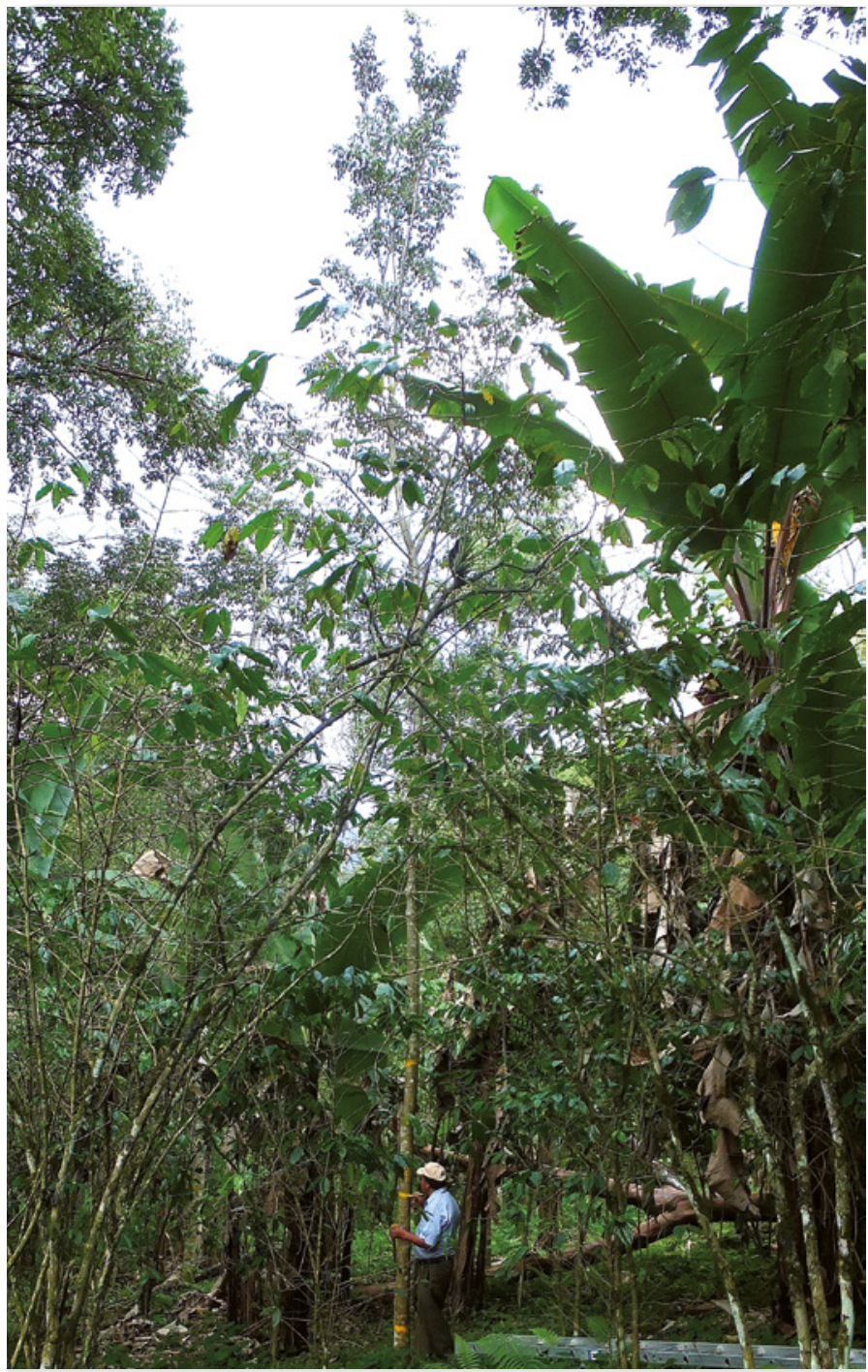

Photo 4.

Tree with a canopy completely exposed to vertical light, but with lateral competition (category 4 of the Dawkins index).

These conditions seem to promote the development of straight stems and narrow crowns with thin lateral branches.

Photo A. Suárez-Islas. 


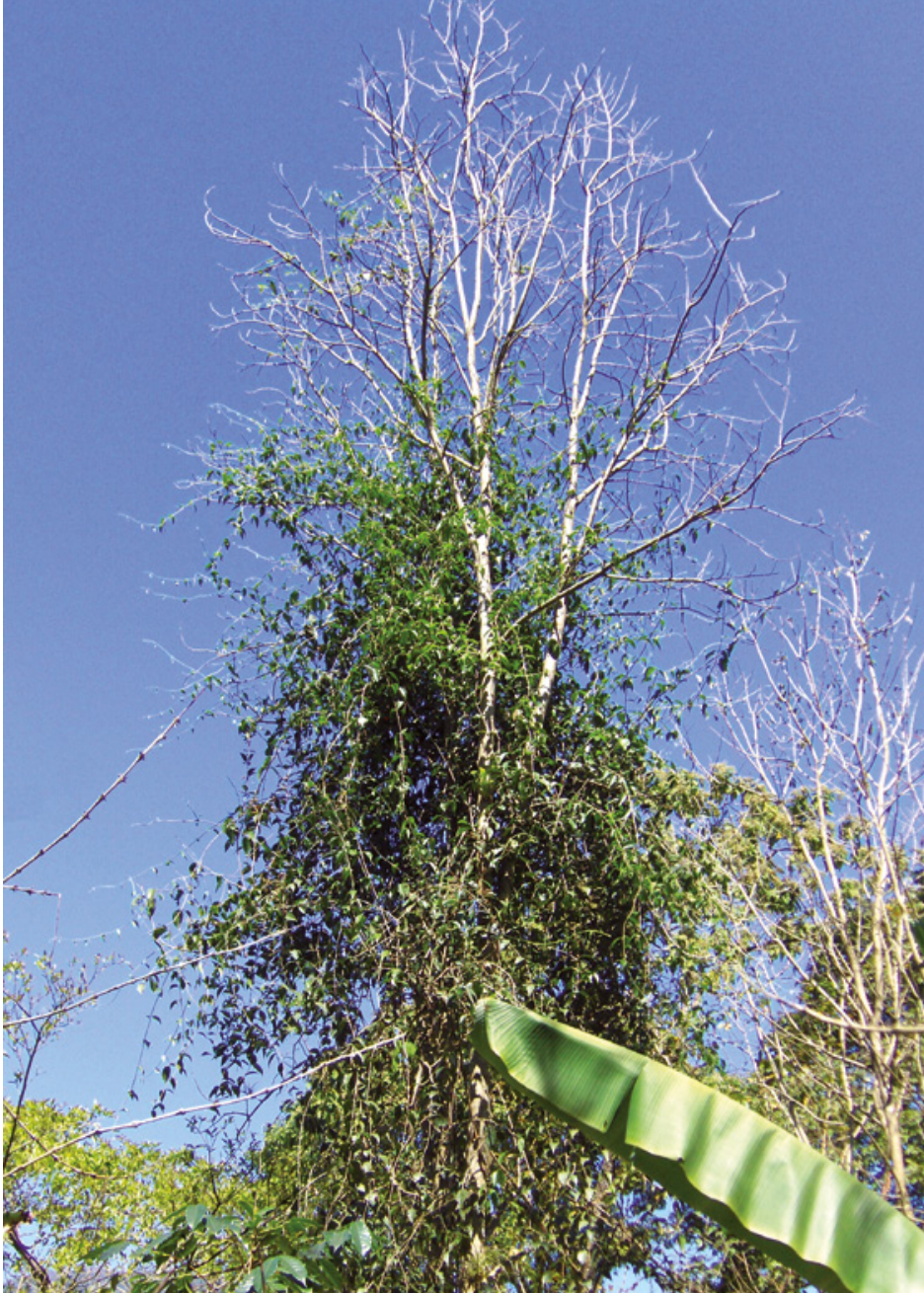

Photo 5.

Tree infested by true mistletoe in approximately the lower half of the crown, which corresponds to category 2 of Vázquez (1993). The photo corresponds to the cold and dry season (February) when the trees almost completely lose their foliage.

Photo A. Suárez-Islas.

and bring benefits to the nutrition of associated crops, such as coffee and banana.

Forest management recommendations include, as a priority, conducting true mistletoe control practices such as pruning out the parasite, focusing on the most affected trees (medium and severe degrees of infestation) and pruning thin branches to keep at least one-third of the crown free of mistletoe; thinning should be used as a complement to pruning (Cibrián and Alvarado, 2007; Díaz-Limón et al., 2016). Severely infested trees competing with healthy or mildly infested trees should be removed, and it is also recommendable to reduce competition in high-density zones to provide more space for the crowns of trees nearing harvest and where there is a risk of affecting the yield of associated crops due to excessive shade. Another possible option is chemical control with herbicides (ethephon) injected into the host's trunk (Contreras-Ruiz et al., 2018); but it is necessary to carry out tests with different doses and times of application.

Preserving other native fruit and timber trees in the Permanent Measurement Plot (PMP) is also important. Juglans pyriformis Liebm. seems to be unaffected by true mistletoe and is also a precious wood species; Diphysa sennoides Benth. and Leucaena sp. produce hardwood that can be used as posts or as firewood; Dendropanax arboreus (L.) Decne. \& Planch. provides soft wood, useful for construction; Persea schediana Nees produces edible fruits, highly appreciated by the local population; while Ficus sp. fruits serve for wild animals (Montagnini et al., 2008). Therefore, these species could be considered in a model of $D$. palo-escrito agroforestry plantation as part of the shade canopy. Their role would be to prevent true mistletoe from spreading and to diversify the products and services provided by coffee plantations. Multi-strata agroforestry systems can accelerate forest succession and regeneration, reducing restoration costs through the production of associated crops to provide food and income to the farmer over time (Oliveira and Carvalhaes, 2016).

A coffee production reactivation strategy in the state of Hidalgo should include $D$. palo-escrito management, sustainable development, and conservation by promoting enrichment plantings of this species in coffee plantations. Coffee-producing areas in the state of Hidalgo are predominantly inhabited by highly marginalized indigenous populations who require to improve their economic income (López-Pérez, 2002). In a coffee plantation enriched with precious wood trees, the high prices of fine timbers in the international market could compensate for the long wait to harvest the trees, while associated crops can provide food and income to farmers throughout the turn; thus, wood would represent natural capital and a green heritage for future generations (Cervantes-Maldonado, 2016).

\section{Conclusion}

The present study confirmed that growth in diameter and height of Dalbergia palo-escrito trees in an enrichment planting were positively associated with illumination received by tree crowns. Infestation by true mistletoe was more intense in trees receiving higher amounts of light on the crown and presenting more significant diameter growth; infestation showed a trend to spread to crowns receiving less light. Pruning out the true mistletoe as a control strategy is a recommended forest management practice, as well as releasing poorly illuminated trees from competition and preserving the shade canopy of other native species. As for the economic and biological enrichment of coffee plantations in the Sierra Madre Oriental in the state of Hidalgo, promoting $D$. palo-escrito trees as a source of precious wood in a combined strategy including sustainable exploitation and conservation should be promoted.

\section{Acknowledgments}

We are grateful to Shamed Popoca Paredes for his valuable assistance in the field. This research was partially funded by the Secretaria de Educación Publica under project PIFI2011-13MSU0017T-05. We also thank the four anonymous reviewers for providing us with many helpful suggestions. 


\section{References}

Acosta P. R., Cházaro B. R., 1992. Los muérdagos del estado de Tlaxcala. Tlaxcala, México, Jardín Botánico Tizatlán, Gobierno de Tlaxcala, Folleto Divulgativo No. 17, 89 p.

Alder D., Synnott T. J., 1992. Permanent sample plot techniques for mixed tropical forest. Oxford, UK, Oxford Forestry Institute, 124 p. https://agris.fao.org/agris-search/search. do? recordID=GB2012106028

Carmona-Valdovinos T. F., 2003. Laudería: oficio de centenaria tradición. La Ciencia y el Hombre, 3: 59-62. https://cdigital. uv.mx/bitstream/handle/123456789/5559/20033P59. pdf? sequence $=2$ \&isAllowed $=y$

Cartujano S., Zamudio S., Alcántara O., Luna I., 2002. El bosque mesófilo de montaña en el municipio de Landa de Matamoros, Querétaro, México. Boletín de la Sociedad Botánica de México, 70: 14-43. http://www.redalyc.org/pdf/577/57707002.pdf

Cervantes-Maldonado A., 2016. La conservación del granadillo en México, una carrera contra el tiempo. Biodiversitas, 128: 6-11. http:// bioteca.biodiversidad.gob.mx/ianium/Documentos/12765.pdf

Cervantes A., Linares J., Quintero E., 2019. An updated checklist of the Mexican species of Dalbergia (Leguminosae) to aid in its conservation efforts. Revista Mexicana de Biodiversidad, 90: e902528. https:// doi.org/10.22201/ib.20078706e.2019.90.2528

Cibrián T. D., Alvarado R. D., 2007. Muérdago Struthanthus - Struthanthus mistletoe. In: Cibrián T. D., Alvarado R. D., García D. S. E. (eds). Enfermedades forestales en México - Forest diseases in Mexico. Universidad Autónoma Chapingo, México, 587 p.

CONABIO, 2010. El bosque mesófilo de montaña en México: Amenazas y oportunidades para su conservación y manejo sostenible. México, Comisión Nacional para el Conocimiento y Uso de la Biodiversidad, 168-182. http://bioteca.biodiversidad.gob.mx/janium-bin/detalle. pl?ld=20200625022224

CITES (Convention on International Trade In Endangered Species of Wild Fauna and Flora), 2016. CoP 17 Prop. 54. Consideration of proposals for amendment of Appendices I and II. Seventeenth meeting of the Conference of the Parties, Johannesburg (South Africa), 24 September - 5 October 2016, 63 p. https://cites.org/ sites/default/files/eng/cop/17/prop/060216/E-CoP17-Prop-54.pdf

Contreras-Ruiz C., Alvarado R. D., Cibrián T. D., Valdovinos-Ponce G., 2018. Control químico con etefón (ácido 2-cloroetil fosfónico) del muérdago verdadero Struthanthus interruptus (Kunth) G. Don. Agrociencia, 52 (5): 741-755. http://www.scielo.org.mx/scielo. php? script=sci_arttext\&pid=S1405-31952018000500741

Costa M. S., Ferreira K. E. B., Botosso P. C., Callado C. H., 2015. Growth analysis of five Leguminosae native tree species from a seasonal semidecidual lowland forest in Brazil. Dendrochronologia, 36: 23-32. https://doi.org/10.1016/j.dendro.2015.08.004

Detlefsen G., Marmillod D., Scheelje M., Ibrahim M., 2012. Protocolo para la instalación de parcelas permanentes de medición de la producción maderable en sistemas agroforestales de Centroamérica. Turrialba, Costa Rica, Centro Agronómico Tropical de Investigación y Enseñanza, 38 p. https://es.scribd.com/document/381618707/ Protocolo-para-la-instalacion-de-parcelas-permanentes-demedicion-de-la-produccion-maderable-en-sistemas-agroforestalesde-Centroamerica

Díaz-Limón M. P., Cano-Santana Z., Queijeiro-Bolaños M. E., 2016. Mistletoe infection in an urban forest in Mexico City. Urban Forestry \& Urban Greening, 17: 126-134. https://doi.org/10.1016/i. ufug.2016.04.004

DOF (Diario Oficial de la Federación), 2019. Anexo Normativo III NOM059-SEMARNAT-2010 Norma Oficial Mexicana, Protección ambiental-
Especies nativas de México de flora y fauna silvestres. Categorías de riesgo y especificaciones para su inclusión, exclusión o cambio. Lista de especies en riesgo. Diario Oficial de la Federación.

Ehleringer J. R., Schulze E. D., Ziegler H., Lange O. L., Farquhar G. D., Cowar I. R., 1985. Xylem-tapping mistletoes: water or nutrient parasites? Science, 227: 1479-1481. https://doi.org/10.1126/ science.227.4693.1479

Finegan B., Camacho M., Zamora N., 1999. Diameter increment patterns among 106 tree species in a logged and silviculturally treated Costa Rican rain forest. Forest Ecology and Management, 121 (3): 159-176. https://doi.org/10.1016/S0378-1127(98)00551-9

Galván O., Louman B., Galloway G., Obando G., 2005. Efecto de la iluminación de copa en el crecimiento de Pentaclethra macroloba y Goethalsia meiantha, implicaciones para la silvicultura de los bosques tropicales húmedos. Recursos Naturales y Ambiente, 46-47: 117-126. http://orton.catie.ac.cr/repdoc/A3292e/A3292e.pdf

González-Espinoza M., Meave J. A., Lorea-Hernández F. G., IbarraManríquez G., Newton A. C., 2011. The Red List of Mexican cloud forest trees. IUCN, 152 p. https://www.iucn.org/content/red-listmexican-cloud-forest-trees

González-Espinoza M., Meave J. A., Ramírez-Marcial N., Toledo-Aceves T., Lorea-Hernández F. G., Ibarra-Manríquez G., 2012. Los bosques de niebla de México: conservación y restauración de su componente arbóreo. Ecosistemas, 21: 36-52. https://www.revistaecosistemas. net/index.php/ecosistemas/article/view/26

Howell B. E., Mathiasen R. L., 2004. Growth impacts of Psittacanthus angustifolius Kuijt on Pinus oocarpa Schiede in Honduras. Forest Ecology and Management, 198 (1-3): 75-88. https://doi. org/10.1016/j.foreco.2004.03.047

Interián-Ku V. M, Vaquera-Huerta H., Valdez-Hernández J. I., GarcíaMoya E., Romero-Manzanares A., Borja-De la Rosa A., 2014. Influencia de factores morfológicos y ambientales sobre el crecimiento en diámetro de Caesalpinia gaumeri Greenm en un bosque tropical caducifolio, en México. Revista Chapingo Serie Ciencias Forestales y del Ambiente, 20 (3): 255-270. http://www.scielo.org.mx/scielo. php?script=sci arttext\&pid=S2007-40182014000300010

Jardel-Peláez E. J., Cuevas-Guzmán R., Santiago-Pérez A. L., Rodríguez-Gómez J. M., 2014. Ecología y manejo de los bosques mesófilos de montaña en México. In: Gual-Díaz M., Rendón-Correa A. (eds). Bosques mesófilos de montaña de México: diversidad, ecología y manejo. México, Comisión Nacional para el Conocimiento y Uso de la Biodiversidad, 141-188. https://www.researchgate.net/ publication/274780080 Ecologia y manejo de los bosques mesofilos de montana en Mexico\#fullTextFileContent

Keeling H. C., Phillips O. L., 2007. A calibration method for the crown illumination index for assessing forest light environments. Forest Ecology and Management, 242 (2-3): 431-437. http://doi. org/10.1016/j.foreco.2007.01.060

López-Pérez S., 2002. De lo global a lo local: cambios de cultivos y estrategias de sobrevivencia ante la crisis del mercado internacional del café, el caso de la Sierra Otomí-Tepehua en el estado de Hidalgo. Problemas del Desarrollo, 33: 131-162. http://dx.doi.org/10.22201/ iiec.20078951e.2002.131.7454

López L., Villalba R., 2015. Criterios de gestión forestal para 12 especies de los Bosques Nativos Tropicales de Bolivia a través de métodos dendrocronológicos. Ecosistemas, 24 (2): 24-29. https:// doi.org/10.7818/ECOS.2015.24-2.04

Manzano-Méndez F., Valdez-Hernández J. I., López-López M. A., Vaquera-Huerta H., 2010. Crecimiento en diámetro de Zanthoxylum kellermanii P. Wilson en una selva perennifolia del norte de Oaxaca, México. Madera y Bosques, 16 (2): 19-33. http://www.scielo.org.mx/ scielo.php?script=sci_arttext\&pid=S1405-04712010000200002

Méndez-Paiz B. A., Serech-Van Haute A., 2018. Native species valuable timber plantations in Northern Guatemalan Humid Lowlands: ecological features and silvicultural feasibility. Ciencia, Tecnología y Salud, 5 (2): 136-150. https://digi.usac.edu.gt/ojsrevistas/index. php/cytes/article/view/486 
Millet J., Tran N., Vien Ngoc N., Tran Thi T., Prat D., 2013. Enrichment planting of native species for biodiversity conservation in a logged tree plantation in Vietnam. New Forests, 44: 369-383. https://doi. org/10.1007/s11056-012-9344-6

Montagnini F., Suárez-Islas A., Santana M. R., 2008. Participatory approaches to ecological restoration in Hidalgo, Mexico. Bois et Forêts des Tropiques, 295 (1): 5-20. http://bft.cirad.fr/cd/BFT 295 5-20. pdf

Mourão F. A., Jacobi C. M., Figueira J. E. C., Batista E. K. L., 2009. Effects of the parasitism of Struthanthus flexicaulis (Mart.) Mart. (Loranthaceae) on the fitness of Mimosa calodendron Mart. (Fabaceae), an endemic shrub from rupestrian fields over ironstone outcrops, Minas Gerais State, Brazil. Acta Botanica Brasilica, 23: 820825. http://dx.doi.org/10.1590/S0102-33062009000300023

NOM-021-SEMARNAT, 2002. Norma Oficial Mexicana NOM-021SEMARNAT, Especificaciones de fertilidad, salinidad y clasificación de suelos, estudio, muestreo y análisis. Diario Oficial de la Federación. http://biblioteca.semarnat.gob.mx/janium/Documentos/Ciga/ libros2009/D02280n.pdf

Oliveira R. E. D., Carvalhaes M. A., 2016. Agroforestry as a tool for restoration in Atlantic forest: can we find multi-purpose species? Oecologia Australis, 20 (4): 425-435. https://doi.org/10.4257/ oeco.2016.2004.03

Olsen M. W., 2003. True mistletoes. Tucson, Arizona, USA, The University of Arizona Cooperative Extension, College of Agriculture and Life Sciences, 3 p. http://hdl.handle.net/10150/146718

Parrotta J. A., 2000. Dalbergia sisso Roxb. Sisso, Indian rosewood. In: Francis J. K., Lowe C. A. (eds). Bioecología de árboles nativos y exóticos de Puerto Rico y las Indias Occidentales. Río Piedras, Puerto Rico, Departamento de Agricultura de los Estados Unidos, 190-194. https://data.fs.usda.gov/research/pubs/iitf/Bioecologia gtr15.pdf?

Pérez-Olvera C. P., Vélez-liménez S., Serrano-García A., RochinGarcía B., 2002. La madera de las guitarras de Paracho, Michoacán. ContactoS, 44: 45-53. http://www2.izt.uam.mx/newpage/ contactos/anterior/n44ne/guitarra.pdf

Piotto D., Víquez E., Montagnini F., Kanninen M., 2004. Pure and mixed forest plantation with native species of the dry tropics of Costa Rica: a comparison of growth and productivity. Forest Ecology and Management, 190 (2-3): 359-372. https://doi.org/10.1016/j. foreco.2003.11.005

Ramos D., Castro V., Sánchez E., 2015. Caracterización de la vegetación a lo largo de una gradiente altitudinal en la comunidad de Cochahuayco, cuenca media del río Lurín, Lima. Ecología Aplicada, 14 (1): 11-25. http://www.scielo.org.pe/scielo.php?pid=S172622162015000100002\&script=sci_abstract

Rzedowski J., Guridi-Gómez L. I., 1988. El palo-escrito, árbol de madera preciosa-una nueva especie mexicana de Dalbergia (Leguminosae, Papilionoideae). Acta Botánica Mexicana, 4: 1-8. https://www.redalyc.org/pdf/574/57400401.pdf

Rzedowski J., 2006. Vegetación de México (1ª Edición digital). Comisión Nacional para el Conocimiento y Uso de la Biodiversidad, México. CONABIO, Editorial Limusa, 502 p. http://bioteca. biodiversidad.gob.mx/janium/Documentos/7369.pdf

Salgado J., 2012. Producción de madera en sistemas agroforestales con café. In: Detlefsen G., Somarriba E. (eds). Producción de madera en sistemas agroforestales de Centroamérica. Turrialba, Costa Rica, Centro Agronómico Tropical de Investigación y Enseñanza, Manual técnico no. 109, 145-160. http://repositorio.bibliotecaorton.catie. ac.cr/bitstream/handle/11554/3512/Produccion_de_madera_en sistemas agroforestales.pdf

Schneider T., Ashton M. S., Montagnini F., Milan P. P., 2014. Growth performance of sixty tree species in smallholder reforestation trials on Leyte, Philippines. New Forests, 45 (1): 83-96. https://doi. org/10.1007/s11056-013-9393-5

Sprent J. I., Parsons R., 2000. Nitrogen fixation in legume and nonlegume trees. Field Crops Research, 65: 183-196. https://doi. org/10.1016/S0378-4290(99)00086-6

UNAM, 2013. Atlas climático digital de México, Estado de Hidalgo. Centro de Ciencias de la Atmósfera, online. http://atlasclimatico. unam.mx/atlas/hgo/hgo.html

Vázquez C. I., 1993. Contribución al conocimiento del muérdago verdadero (Psittacanthus spp.) en México. Uruapan, México, Instituto Nacional de Investigaciones Forestales Agrícolas y Pecuarias, Boletín Técnico No. 11. http://ri.uaemex.mx/ bitstream/20.500.11799/67857/3/Tesis+mu\%C3\%A9rdago.pdf

Winfield K., Scott M., Grayson C., 2016. Global status of Dalbergia and Pterocarpus rosewood producing species in trade. For the Convention on International Trade in Endangered Species, 17th conference of the parties, Johannesburg (24 September - 5 October 2016). https:// www.blackwoodconservation.org/wp-content/uploads/2019/07/ Global-Status-of-Dalbergia-and-Pterocarpus-Rosewood-CITES-2017pdf

\section{Suárez-Islas et al. - Author’s contributions}

\section{CONTRIBUTOR ROLE CONTRIBUTOR NAMES}

\begin{tabular}{|c|c|}
\hline Conceptualization & A. Suárez-Islas \\
\hline Data Curation & $\begin{array}{l}\text { A. Suárez-Islas, } \\
\text { J. Capulín-Grande }\end{array}$ \\
\hline Formal Analysis & $\begin{array}{l}\text { A. Suárez-Islas, } \\
\text { J. Capulín-Grande }\end{array}$ \\
\hline Funding Acquisition & $\begin{array}{l}\text { A. Suárez-Islas, } \\
\text { J. Capulín-Grande, } \\
\text { J. J. Mateo-Sánchez }\end{array}$ \\
\hline Investigation & $\begin{array}{l}\text { A. Suárez-Islas, } \\
\text { J. Capulín-Grande, } \\
\text { J. J. Mateo-Sánchez }\end{array}$ \\
\hline Methodology & $\begin{array}{l}\text { A. Suárez-Islas, } \\
\text { J. Capulín-Grande }\end{array}$ \\
\hline Project Administration & A. Suárez-Islas \\
\hline Resources & $\begin{array}{l}\text { A. Suárez-Islas, } \\
\text { J. Capulín-Grande, } \\
\text { J. J. Mateo-Sánchez }\end{array}$ \\
\hline Software & A. Suárez-Islas \\
\hline Supervision & A. Suárez-Islas \\
\hline Validation & $\begin{array}{l}\text { A. Suárez-Islas, } \\
\text { J. Capulín-Grande }\end{array}$ \\
\hline Visualization & A. Suárez-Islas \\
\hline $\begin{array}{l}\text { Writing - Original } \\
\text { Draft Preparation }\end{array}$ & A. Suárez-Islas \\
\hline $\begin{array}{l}\text { Writing - Review } \\
\text { \& Editing }\end{array}$ & $\begin{array}{l}\text { A. Suárez-Islas, } \\
\text { J. Capulín-Grande, } \\
\text { J. J. Mateo-Sánchez }\end{array}$ \\
\hline
\end{tabular}

